\title{
Combined impacts of ENSO and MJO on the 2015 growing season drought on the Canadian Prairies
}

\author{
Zhenhua Li ${ }^{1,2}$, Yanping $\mathrm{Li}^{1}$, Barrie Bonsal ${ }^{3}$, Alan H. Manson ${ }^{2}$, and Lucia Scaff ${ }^{1}$ \\ ${ }^{1}$ Global Institute for Water Security, University of Saskatchewan, Saskatoon, Saskatchewan, Canada \\ ${ }^{2}$ Institute of Space and Atmospheric Studies, University of Saskatchewan, Saskatoon, Saskatchewan, Canada \\ ${ }^{3}$ National Hydrology Research Centre, Environment and Climate Change Canada, Saskatoon, Saskatchewan, Canada
}

Correspondence: Yanping Li (yanping.li@usask.ca) and Zhenhua Li (zhenhua.li@usask.ca)

Received: 7 February 2018 - Discussion started: 23 February 2018

Revised: 23 July 2018 - Accepted: 23 July 2018 - Published: 1 October 2018

\begin{abstract}
Warm-season precipitation on the Canadian Prairies plays a crucial role in agricultural production. This research investigates how the early summer 2015 drought across the Canadian Prairies is related to the tropical Pacific forcing. The significant deficit of precipitation in May and June 2015 coincided with a warm phase of the El Niño-Southern Oscillation (ENSO) and a negative phase of Madden-Julian Oscillation (MJO)-4 index, which favour a positive geopotential height (GPH) anomaly in western Canada. Our further investigation during the instrumental record (1979-2016) shows that warm-season precipitation in the Canadian Prairies and the corresponding atmospheric circulation anomalies over western Canada teleconnected with the lower boundary conditions in the tropical western Pacific. Our results indicate that MJO can play a crucial role in determining the summer precipitation anomaly in the western Canadian Prairies when the equatorial central Pacific is warmer than normal (NINO4>0) and MJO is more active. This teleconnection is due to the propagation of a stationary Rossby wave that is generated in the MJO-4 index region. When the tropical convection around MJO-4 index region (western tropical Pacific, centred over $140^{\circ} \mathrm{E}$ ) is more active than normal (NINO4 $>0$ ), Rossby wave trains originate from the western Pacific with wavenumbers determined by the background mean wind and meridional absolute vorticity gradient. Under warm NINO4 conditions waves are generated with smaller wavenumbers compared to cold NINO4 conditions. These waves under warm NINO4 can propagate into the mid-latitudes over North America, causing a persistent anomalous ridge in the upper level over western Canada, which favours dry conditions over the region.
\end{abstract}

\section{Introduction}

The Canadian Prairies depend on summer precipitation especially during the early to mid-growing season (May through August) when the majority of annual precipitation normally occurs (e.g., Bonsal et al., 1993). High natural variability in growing season precipitation causes periodic occurrences of extreme precipitation ( $\mathrm{Li}$ et al., 2017; Liu et al., 2016) and droughts that are often associated with reduced agriculture yields, low streamflow, and increased occurrence of forest fires (Wheaton et al., 2005; Bonsal and Regier, 2007). Drought events with great environmental and economic impacts on the Canadian Prairies have occurred in 1961, 1988, 2001-2002, and as recent as 2015 (Dey, 1982; Liu et al., 2004; Bonsal et al., 1999; Wheaton et al., 2005; Shabbar et al., 2011; Bonsal et al., 2013; Szeto et al., 2016). The subseasonal forecast of precipitation for the growing season is crucial for the agriculture, water resource management, and the economy of the region. Therefore, an investigation into the causes of inter-annual variability in the growing season precipitation of the Canadian Prairies is needed.

Low precipitation and extended dry periods on the Canadian Prairies are often associated with an upper-level ridge and a persistent high pressure centred over the region (Dey, 1982; Liu et al., 2004). These prolonged atmospheric anomalies often concurred with abnormal boundary layer conditions such as a large-scale sea surface temperature (SST) anomalies in the Pacific Ocean (Shabbar and Skinner, 2004). Large-scale oscillation in the SST anomalies in the Pacific Ocean, namely El Niño and the Pacific Decadal Oscillation (PDO), can affect the hydroclimatic pattern in summer over North America, although the strongest impacts of 
these boundary conditions occur during the boreal winter. Inter-annual variability such as El Niño-Southern Oscillation (ENSO) is linked with extended droughts in the Prairies (Bonsal et al., 1999; Shabbar and Skinner, 2004). Interdecadal oscillations such as the PDO and the Atlantic Multidecadal Oscillation (AMO) also affect the seasonal temperature and precipitation in the Canadian Prairies (Shabbar et al., 2011).

ENSO's relationship with the Canadian Prairies' precipitation has been studied extensively. Previous investigations (e.g., Shabbar et al., 2011) have found that El Niño events are associated with a summer moisture deficit in western Canada while La Niña events cause an abundance of moisture in far western Canada (British Columbia and Yukon). However, they also noted that, although tropical SST variability accounted for some aspects of the large-scale circulation anomalies that influence the Canadian Prairies meteorological drought, a consistent and clear-cut relationship was not found. The warm phase of ENSO often favours drought in this region, especially during the growing season after the mature phase of El Niño (Bonsal and Lawford, 1999; Shabbar and Skinner, 2004). The positive North Pacific Mode (NPM, Hartmann et al., 2015) like the North Pacific SST anomaly pattern often follows a matured El Niño, and the accompanying atmospheric ridging leads to extended dry spells over the Prairies during the growing season (Bonsal and Lawford, 1999). Furthermore, in association with the recent North Pacific SST anomaly from 2013 to 2014, researchers have attributed the precipitation deficit in California during 2013 to the anomalous upper-level ridge over western North America (Wang et al., 2014; Szeto et al., 2016).

The aforementioned SST variations mostly vary on interannual and decadal scales. Another important factor that affects the weather patterns in North America is the MaddenJulian Oscillation (MJO), an intra-seasonal (40-90 days) oscillation in convection and precipitation pattern over the tropics (Madden and Julian, 1971; Zhang, 2005; Riddle et al., 2013; Carbone and Li, 2015). MJO is a coupled atmosphereocean oscillation involving convection and large-scale equatorial waves, which produces an eastward propagation of the tropical convection anomaly (Madden and Julian, 1971). The MJO affects the winter temperature and precipitation in North America and Europe through its impact on moisture transport associated with the "Pineapple Express" and its effects on the North Atlantic Oscillation and stratospheric polar vortex (Cassou, 2008; Garfinkel et al., 2012; Rodney et al., 2013). MJO is also connected to the summer precipitation anomalies in the southwestern United States (Lorenz and Hartmann, 2006). During the warm season, MJO's impact on the Canadian Prairies' precipitation has not been thoroughly investigated as MJO's amplitude is weak during spring and early summer. The amplitude of MJO in spring and early summer is related to the inter-annual variation of the tropical SST, especially the SST in the central Pacific (Hendon et al., 2007; Marshall et al., 2016). MJO in terms of the Real- time Multivariate MJO index (RMM, Wheeler and Hendon, 2004) was extremely strong in the early spring of 2015 with a positive PDO-like SST anomaly in the central Pacific and, at the same time, El Niño started to strengthen.

MJO activities in the western Pacific under the modulation of inter-annual SST variability have the potential to act together with ENSO and impact mid-tropospheric circulation over western Canada and, thus, warm-season precipitation over the Canadian Prairies. The goal of this study is to demonstrate that MJO has contributed to the 2015 growing season drought in the Canadian Prairies through the propagation of stationary Rossby waves. Subsequently, further investigations are carried out to determine if similar relationships exist in association with other summer extreme precipitation events during the instrumental record (1979-2016). Section 2 provides the datasets and methodology used in this paper while Sect. 3 presents the analysis of the upper-level circulation anomaly and SST pattern associated with the 2015 drought. This is followed by the examination of the effects of central Pacific SST anomalies and MJO on the summer precipitation in the Canadian Prairies. The mechanism by which MJO affects summer precipitation when equatorial central Pacific SST is warmer than normal is discussed in Sect. 4, followed by the summary and concluding remarks in Sect. 5 .

\section{Data and methodology}

Multiple observation and reanalysis datasets are used to investigate the circulation anomalies associated with the Canadian Prairies' growing season (May-August) precipitation. The observed precipitation is taken from the Climate Prediction Center (CPC) Merged Analysis of Precipitation (CMAP) dataset (Xie and Arkin, 1997; NOAA CPC, 2017a). Geopotential height (GPH) fields from the National Centers for Environmental Predictions (NCEP) Reanalysis (Kalnay et al., 1996; NOAA NCEP, 2017) and the European Centre for Medium-Range Weather Forecast's (ECMWF) ERA-Interim reanalysis (Dee et al., 2011; ECMWF, 2017) are used to analyze the mid- and upper-level (500 and $200 \mathrm{hPa}$ ) atmospheric circulation patterns.

To represent the central Pacific SST anomaly, the NINO4 SST index (Rayner et al., 2003; NOAA, 2017b) from the CPC of the National Oceanic and Atmospheric Administration (NOAA) is used since the NINO4 region is near the central Pacific and spans over the dateline $\left(5^{\circ} \mathrm{S}-5^{\circ} \mathrm{N}, 160^{\circ} \mathrm{E}-\right.$ $150^{\circ} \mathrm{W}$ ). Multivariate ENSO Index (NOAA, 2017c) data are retrieved from NOAA's Climate Data Center (CDC) website and are used to determine the ENSO phase (Wolter, 1987; Wolter and Timlin, 1993). In particular, the El Niño condition is defined when the monthly mean index of MEI is larger than 0.5 (Andrews et al., 2004).

The Real-time Multivariate MJO series (RMM1 and RMM2; Bureau of Meteorology of Australia, 2017) developed by Wheeler and Hendon (2004) are used to identify 
periods of strong MJO activity as the MJO amplitudes are directly calculated by the square root of RMM1 + RMM2. For MJO intensities over the investigated regions, we used the monthly averaged pentad MJO indices from the NOAA CPC's MJO index (Xue et al., 2002; NOAA CPC, 2017b), which have 10 indices representing locations around the globe. The CPC's MJO index is based on extended empirical orthogonal function (EEOF) analysis on pentad velocity potential at $200 \mathrm{hPa}$. A total of $10 \mathrm{MJO}$ indices on a daily scale are constructed by projecting the daily (00:00 UTC) velocity potential anomalies at $200 \mathrm{hPa}$ (CHI200) onto the 10 timelagged patterns of the first EEOF of pentad CHI200 anomalies (Xue et al., 2002). Negative values of 10 MJO indices correspond to enhanced convection in the 10 regions centred on $20^{\circ} \mathrm{E}, 70^{\circ} \mathrm{E}, 80^{\circ} \mathrm{E}, 100^{\circ} \mathrm{E}, 120^{\circ} \mathrm{E}, 140^{\circ} \mathrm{E}, 160^{\circ} \mathrm{E}$, $120^{\circ} \mathrm{W}, 40^{\circ} \mathrm{W}$, and $10^{\circ} \mathrm{W}$ in the tropics. MJO indices usually vary between -2 and 2 , with negative values indicating above-average convective activities in the corresponding region. Because boreal summer usually corresponds to a period of a weaker amplitude of MJO than the winter, we chose the monthly mean value of -0.3 as the criterion of strong convection which is connected to $\mathrm{MJO}$ as the indices generally vary between -1 and 1 . An MJO-4 index (centred on $140^{\circ} \mathrm{E}$ ) of less than -0.3 was considered a relatively strong convection in the western Pacific, which has been found to be a source region of stationary Rossby waves (Simmons and Hoskins, 1980). SST observations include the Extended Reconstructed Sea Surface Temperature (ERSST) v4 (NOAA, 2017a; Huang et al., 2015). Outgoing Longwave Radiation (NOAA, 2017d) data from NOAA Interpolated Outgoing Longwave Radiation are used to derive the composite of anomalies of OLR for a certain phase of MJO.

Our study focuses on the growing season precipitation in the provinces of Alberta and Saskatchewan in the Canadian Prairies, where the largest deficits were observed in 2015. Specifically, the regional mean precipitation over 115 $102.5^{\circ} \mathrm{W}, 50-57.5^{\circ} \mathrm{N}$ is used (boxed area in Fig. 1, top panel) to represent the Canadian Prairies east of the Rocky Mountains and south of the boreal forest. The chosen region also covers most of the arable land in the Canadian Prairies. Considering the unique MJO-4 and NINO4 indices for 2015, the relationship between the Prairies' warm-season (MayAugust) precipitation with MJO-4 and ENSO during the instrumental records is investigated using correlation and regression. Though the dry months of the 2015 growing season are May and June when MJO-4 was in negative phase, we want to study the statistical relationship between MJO-4 and the Prairies' precipitation in the whole period of the growing season (May-August). The possible mechanism behind the correlation between MJO-4 and the Prairies' warm-season precipitation under El Niño condition is further investigated by analyzing the upper-level circulation associated with convection in the tropical Pacific and stationary Rossby waves in mid-latitudes.
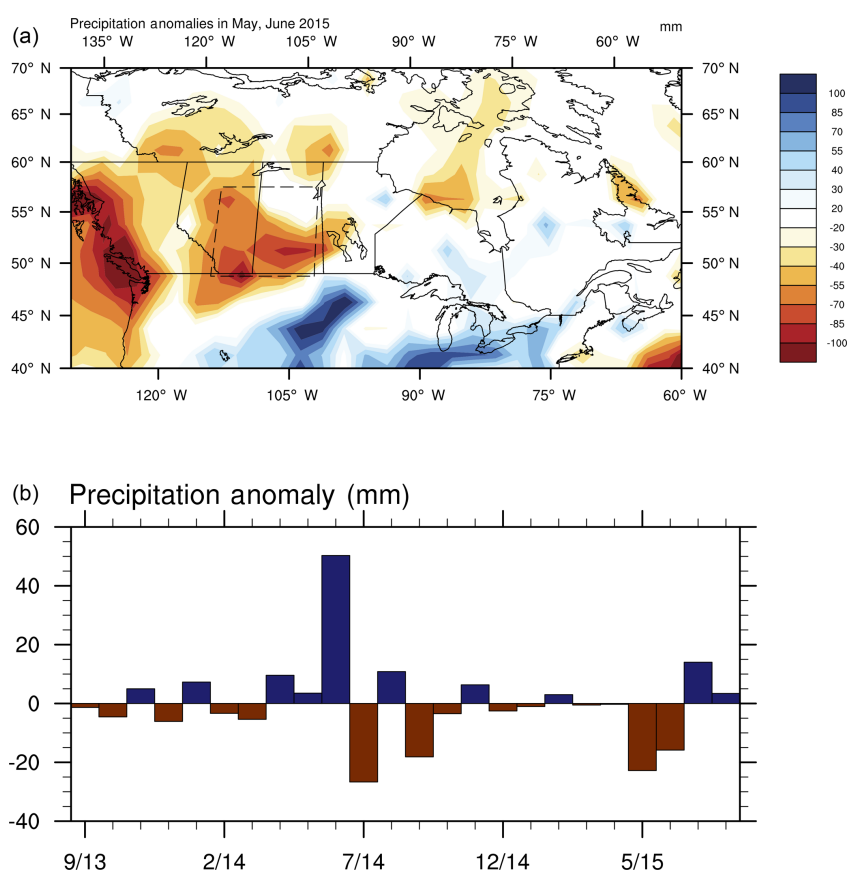

Figure 1. (a) Precipitation anomalies (mm) from CMAP over the region $\left(115-102.5^{\circ} \mathrm{W}, 50-57.5^{\circ} \mathrm{N}\right)$ during May and June 2015. (b) Time series of monthly precipitation anomaly over the boxed region (shown in a) between September 2013 and August 2015.

\section{Results}

\subsection{The 2015 summer drought}

Almost all of western Canada including British Columbia, the southern Northwest Territories, Alberta, and Saskatchewan had negative precipitation anomalies during May and June 2015. The top plot in Fig. 1 shows the precipitation anomaly in percentage relative to the climatology (1981-2010 long-term mean) in Canada during May and June 2015. The bottom plot in Fig. 1 presents the monthly precipitation anomaly averaged over the region encompassed by the dashed lines (top panel in Fig. 1). The average annual cycle of the regional precipitation has a dry period between February and May and June has the largest precipitation in all months. The May and June 2015 precipitation deficit was also accompanied by a relatively dry period from February to April (Fig. 1 and Szeto et al., 2016), which added to the drought conditions.

The $500 \mathrm{hPa}$ geopotential height anomaly averaged in May and June is examined together with the SST anomaly and ENSO, as well as MJO-4 indices for 2014 and 2015. The $500 \mathrm{hPa}$ GPH anomaly for May and June 2015 shows strong positive anomalies near Alaska and the British Columbia coast (Fig. 2), which is consistent with the findings for other episodes of growing season droughts (e.g., Dey, 1982; Bonsal and Wheaton, 2005). Accompanying this anomalous ridge are above-normal SSTs in the northeast Pacific off 


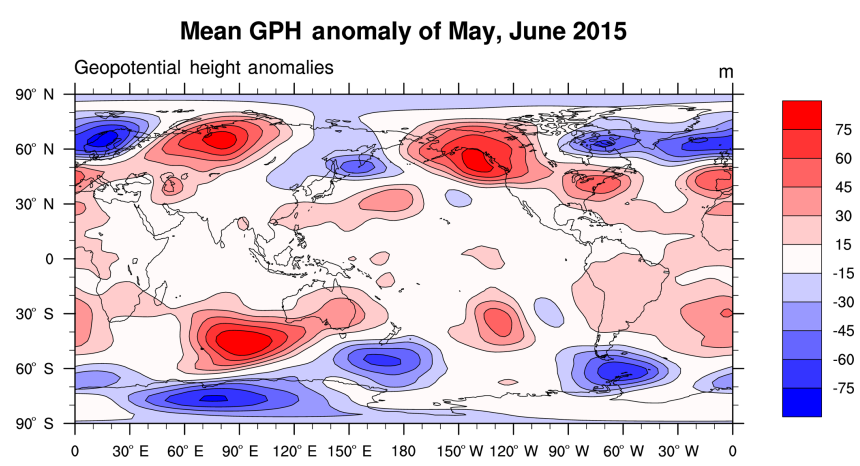

Figure 2. NCEP GPH anomaly at $500 \mathrm{hPa}$ during May and June 2015 when the precipitation deficit was the largest.

the coast of North America and the central-eastern Pacific (Fig. 3). Both ENSO and the NPM are in positive phases that correspond to a warmer SST near the Pacific coast of North America, consistent with the positive GPH anomalies in western Canada and Alaska. The ridge in Alaska/Bering Strait and the one near the British Columbia coast have been previously associated with El Niño and the North Pacific SST anomaly such as NPM (Shabbar et al., 2011). The monthly mean anomalous ridge prevents storms from reaching the British Columbia coast and the Canadian Prairies, causing extended dry spells. Therefore, the GPH anomaly in the early growing season in 2015 is consistent with the precipitation anomaly in these regions. The anomalous upper-level ridge in the western United States and Canada in 2014 and 2015 has also been associated with the developing El Niño and the other main components of Pacific SST variation such as NPM by several recent studies (Hartmann et al., 2015; Lee et al., 2015; Li et al., 2017).

The SST anomaly and the associated oscillations and modes, especially ENSO, show consistent agreement with the observed GPH anomaly pattern. The average SST anomaly during the growing season (May-June, JulyAugust) of 2015 shows a persistent strong positive anomaly in the northeast and eastern equatorial Pacific (Fig. 3), which corresponds to the warm phase of NPM and ENSO. SSTs in the eastern tropical Pacific warmed increasingly since the end of 2014 and qualified as an El Niño in early 2015. The NPM became positive in fall 2013, turned exceptionally strong in 2014, and persisted to 2015 (Hartmann, 2015). The anomalous ridge is concurrent with strong SST anomalies in the tropical Pacific and extratropical North Pacific. NPM, as the third EOF of Pacific SST $\left(30^{\circ} \mathrm{S}-65^{\circ} \mathrm{N}\right)$, has also a strong connection to the anomalous ridge in western North America and trough in the eastern US and Canada in the 20132014 winter (Hartmann, 2015; Lee et al., 2015). During the ENSO-neutral condition in 2013 and 2014, the precursor of ENSO, the so-called "footprinting" mechanism is considered to cause this anomalous ridge in western North America (Wang et al., 2014).
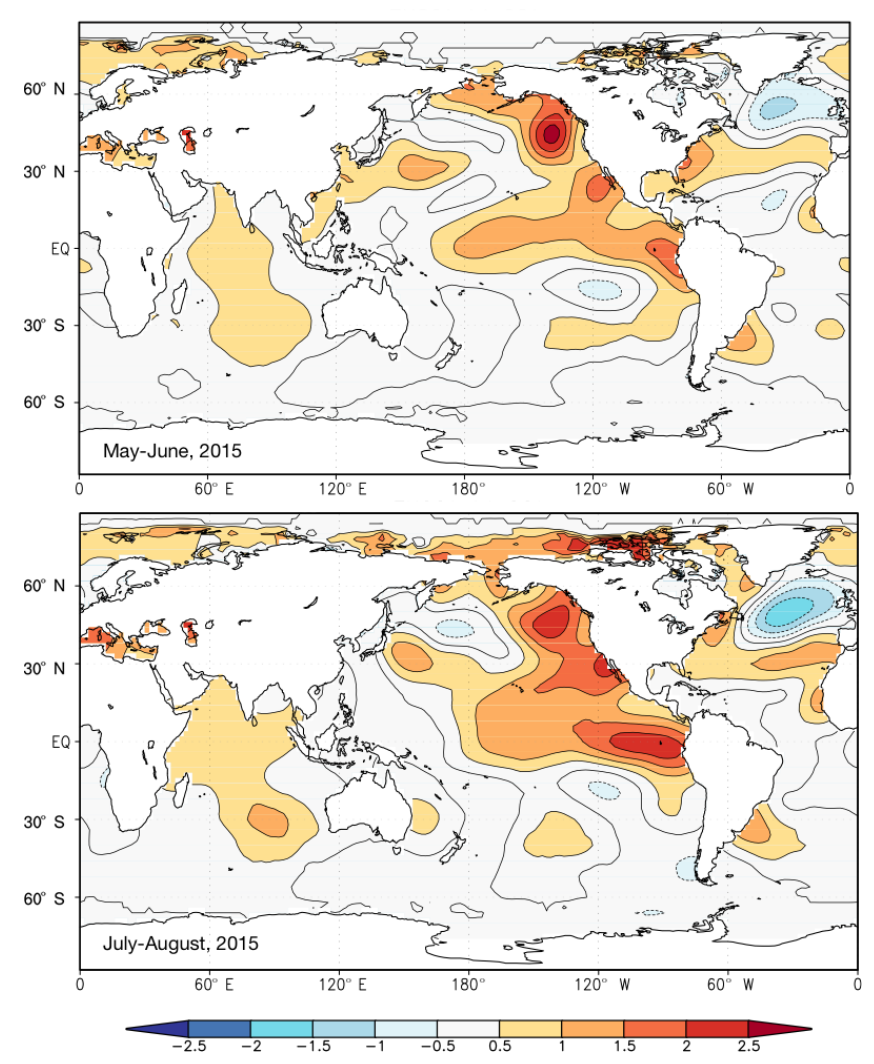

Figure 3. The mean SST anomaly $\left({ }^{\circ} \mathrm{C}\right)$ from ERSST v4 for MayJune and July-August 2015.

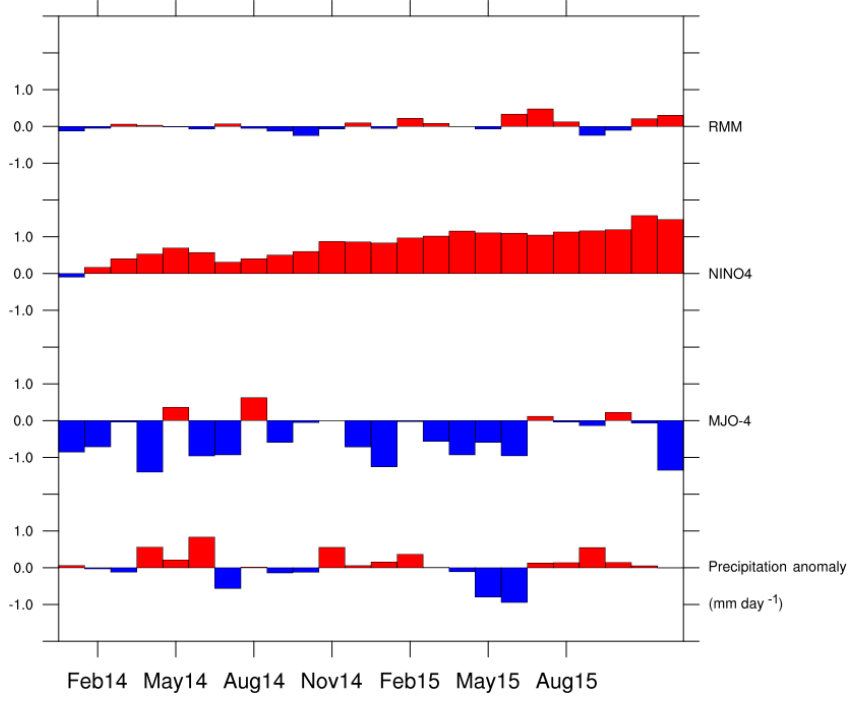

Figure 4. RMM amplitude anomaly, NINO4, MJO-4 indices, and precipitation anomaly of the Canadian Prairies from January 2014 to December 2015.

The variation of the Canadian Prairies' precipitation and its relationship with NINO4 and MJOs are shown in Fig. 4. The time series of the monthly RMM amplitude, NINO4 in- 
Table 1. Correlation between mean precipitation anomaly in the Prairies from CMAP and MEI, as well as MJO-4 indices. MJO indices and CMAP are from 1979 to 2016.

\begin{tabular}{lrrr}
\hline & Correlation & $p$ value & $\begin{array}{r}\text { No. of } \\
\text { sample }\end{array}$ \\
\hline MEI & -0.096 & 0.24 & 156 \\
MJO-4 & 0.18 & 0.023 & 156 \\
MJO-4(NINO4 $>0)$ & 0.33 & 0.0015 & 90 \\
MJO-4(NINO4 $<0)$ & -0.01 & 0.94 & 66 \\
\hline
\end{tabular}

dex, MJO-4 indices, and the Canadian Prairies' precipitation anomaly from January 2014 to December 2015 shows the atmospheric-oceanic circulation indices for the drought in 2015. In May and June 2015, the western Pacific witnessed a strong MJO-4 negative index, whereas in July the MJO-4 index became positive. This corresponds well with the precipitation anomaly in Fig. 1. As shown in Fig. 3, El Niño continued to strengthen in July and August 2015, while at the same time the MJO-4 index increased. The increase in the MJO-4 index indicated that the active convection associated with MJO moved away from the tropical western Pacific region and propagated eastward into the central Pacific. Coincident with this change in MJO, the precipitation in the Canadian Prairies then returned to slightly above normal in July.

The good correspondence of MJO-4 and the negative precipitation anomaly suggests a link between MJO and Prairies precipitation during the growing season. Although El Niño and the associated northeast Pacific SST warm anomaly (i.e., NPM) in summer 2015 can be a contributing factor for the persistent upper-level ridge over the west coast of Canada (Shabbar et al., 2011), it cannot fully explain the drought condition in western Canada, as these SSTs do not guarantee a prolonged dry spell as shown by correlation analysis (Table 1). The negative MJO-4 index concurred with the negative anomaly of the Prairies' growing season precipitation in 2015, which prompts the investigation of their relationship with the instrumental records.

\subsection{Instrumental record}

El Niño and its associated North Pacific SST anomaly may contribute to extended dry spells in Canadian Prairies after the mature phase of El Niño (Bonsal et al., 1993) on an inter-annual timescale. ENSO, however, is not a strong intraseasonal-to-seasonal predictor of Canadian Prairies summer precipitation. The lack of a strong correlation between the Prairies' precipitation and ENSO index can be caused by the fact that many factors can affect the Prairies' precipitation on a seasonal and sub-seasonal scale. Shabbar and Skinner (2004) showed the connection between the warm phase of ENSO and western Canadian drought through singular value decomposition analysis. However, they also found

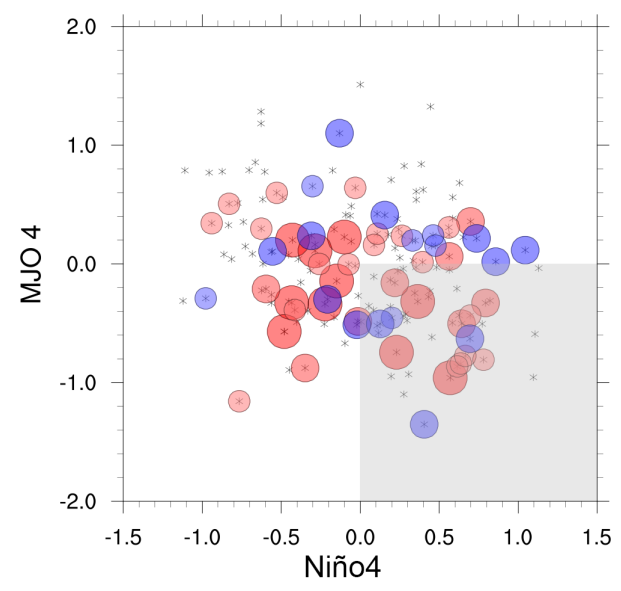

Figure 5. The scatter plot of the monthly precipitation anomaly (mm month ${ }^{-1}$ ) as a function of MJO-4 and NINO4. Each asterisk represents a month from May to August 1979-2016. Circled asterisks denote a month with precipitation anomaly larger than $18 \mathrm{~mm}$ month $^{-1}$. The blue circles are months with positive precipitation anomaly and the red circles are months with negative precipitation anomaly. The sizes of circles denote the magnitudes of the anomalies (large $>30 \mathrm{~mm}^{\text {month }}{ }^{-1}$, medium $>24 \mathrm{~mm}$ month $^{-1}$, small $\left.>18 \mathrm{~mm} \mathrm{month}^{-1}\right)$. The shaded area denotes NINO4 $>0$ and MJO-4 index $<0$.

other modes of SST variation (e.g., the positive phase of PDO) can produce a wet condition in the Prairies. Here we present a new result showing that, under warm central $\mathrm{Pa}$ cific SST conditions (NINO4 $>0$ ), a certain phase of MJO, which connected to the active convection in the tropical western Pacific (Li and Carbone, 2012), plays an important role in modulating the growing season precipitation in the Canadian Prairies.

The correlation coefficients between the mean regional precipitation anomaly over Canadian Prairies and MJO-4 indices and MEI from May to August are shown in Table 1. The correlation between MEI alone and the precipitation anomalies is not significant. The correlation between MJO-4 and precipitation in the Prairies is 0.18 with a $p$ value of 0.023 , which indicates that stronger tropical convection in the equatorial region centred around $140^{\circ} \mathrm{E}$ favours less precipitation in the Canadian Prairies from May to August. When NINO4 is larger than 0 , the correlation between MJO-4 and the growing season precipitation is 0.33 with a $p$ value of 0.0015 . Conversely, the correlation between MJO-4 and Canadian Prairies precipitation is -0.01 when $\mathrm{NINO} 4<0$.

The scatter plot in Fig. 5 shows the distribution of monthly precipitation anomaly versus the MJO-4 index and NINO4 index. Circled asterisks denote a month with a precipitation anomaly larger than $18 \mathrm{~mm} \mathrm{month}^{-1}$ and the red (blue) circles denote a negative (positive) precipitation anomaly. The criterion for precipitation anomaly to be emphasized by the circles is roughly one-third of the mean monthly precipitation in the growing season. The size of the circle repre- 


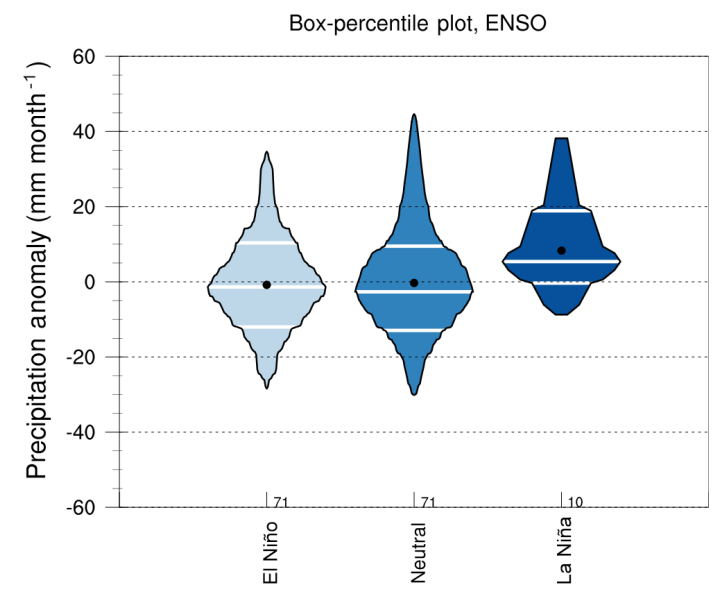

Figure 6. The box-percentile plot of the Canadian Prairies precipitation anomaly during growing season under different ENSO conditions.

sents the magnitude of the monthly precipitation anomalies with $6 \mathrm{~mm}$ month $^{-1}$ interval. The bottom-right quadrant, indicated by shading, shows that negative MJO- 4 corresponds to many more dry months than wet months under NINO4 $>0$ conditions. We noticed that some significant dry months are not in the shaded area, which corresponds to the dry months occurring during La Niña or in the period after the mature phase of El Niño (Bonsal et al., 1999). Summer drought in the Prairies can occur in both phases of ENSO or any other teleconnection indices. For example, for the summer drought that happened in the Prairies from 1999 to 2005, the largescale anomalous patterns of SST first showed La Niña conditions and then became a weak El Niño in the latter half of the period (Hanesiak et al., 2011). Bonsal and Wheaton (2005) showed that the tropospheric atmospheric circulation patterns in 2001 and 2002 lacked the typical meridional flow in the North Pacific and North America during the drought in western Canada. Their results show that the drought in 19992005 was related to the expansion of the continuous drought that happened in the US to the north.

The impact of ENSO on the growing season precipitation over the Canadian Prairies is investigated through Fig. 6. The box-percentile plot in Fig. 6 shows the distribution of monthly Canadian Prairies' precipitation anomalies from May to August along with different ENSO conditions. In general, under El Niño and neutral ENSO conditions, the precipitation anomalies are centred around 0 , and there is no bias toward either end. Under La Niña condition, the mean precipitation has a positive bias. There are only 10 summer months under La Niña condition, whereas there are 71 months under El Niño and neutral conditions.

The distributions of precipitation anomalies versus the MJO-4 index under different ENSO conditions are shown in Fig. 7. For NINO4 $>0$, the precipitation anomaly has a negative tendency when MJO- $4<-0.3$. With NINO4 $<0$, there
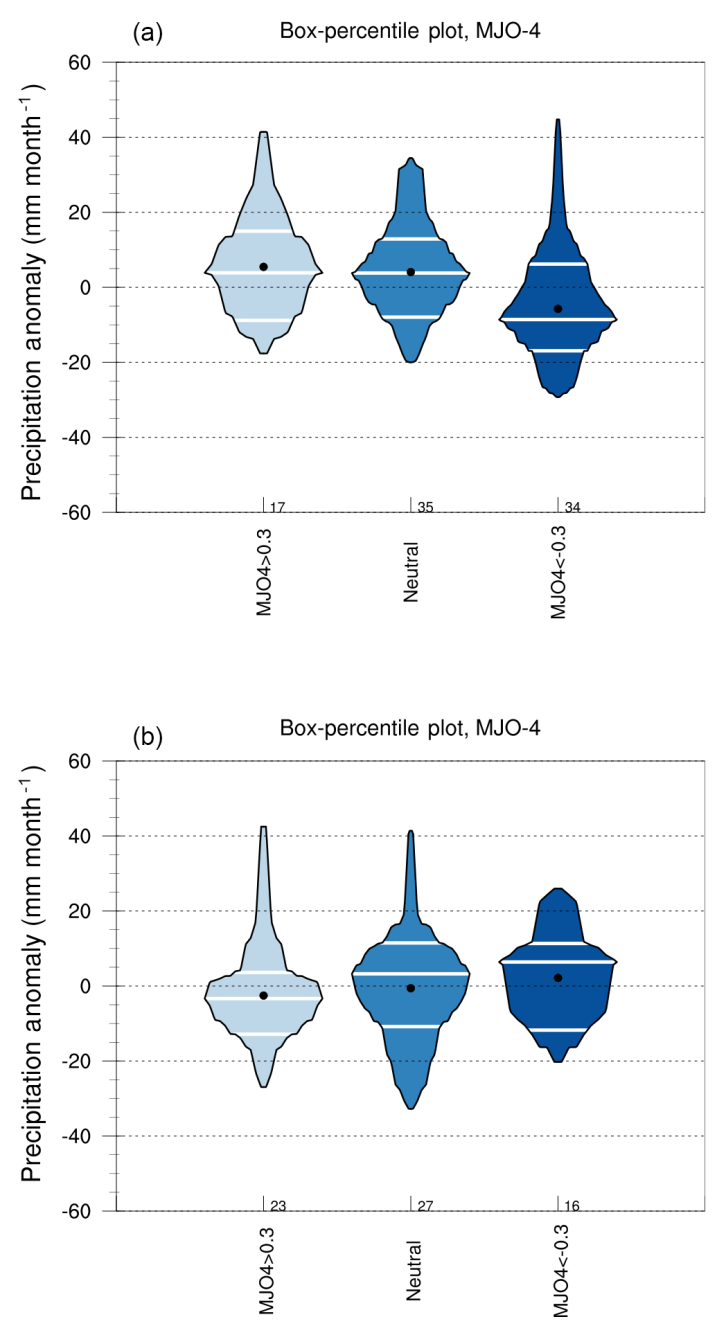

Figure 7. Box-percentile plots of the Canadian Prairies' precipitation anomaly during growing season versus MJO-4 under warm NINO4 (NINO4 >0, a) and cold NINO4 (NINO4<0, b) SST condition.

is no negative tendency for MJO- $4<-0.3$. Therefore, Figs. 6 and 7 agree with the significant correlation between precipitation and MJO-4 under NINO4 >0, relative to ENSO in Table 1 .

The correlation between MJO-4 and the Prairies' precipitation during the growing season leads us to investigate the underlying circulation anomalies. Figure 8 presents the regressed stream function and wind field at $200 \mathrm{hPa}$ in the mid-latitudes (north of $30^{\circ} \mathrm{N}$ ) on the negative MJO-4 index from May to August under warm NINO4 SST condition (NINO4>0.5). In the tropics $\left(10^{\circ} \mathrm{S}-20^{\circ} \mathrm{N}\right)$, during the Northern Hemisphere summer, the OLR, velocity potential, and divergent wind vector are presented. Only regression patterns having $p$ values lower than 0.05 are plotted for OLR and velocity potential. The negative MJO-4 index corresponds to a negative anomaly in OLR, stronger convection, and larger-than-average divergence at $200 \mathrm{hPa}$ in the region 
centre around $150^{\circ} \mathrm{E}$. The strong convection anomaly centres around $150^{\circ} \mathrm{E}, 5^{\circ} \mathrm{N}$ with divergent wind extending well into the subtropics in the Northern Hemisphere. The positive GPH or stream function anomaly extended from Japan to the central Pacific is associated with the enhanced convection and divergence in the upper troposphere over the western tropical-subtropical Pacific. A Rossby wave train linked to the OLR anomaly and strong divergence in the western Pacific propagate eastward into North America in the extratropics. To better demonstrate the propagation of the wave train, we conducted a ray-tracing experiment of stationary Rossby wave following the non-divergent barotropic Rossby wave theory of Hoskins and Karoly (1981) and Hoskins and Ambrizzi (1993). Equation (1) describes the group velocity, which represents the propagation of wave activity. $C_{\mathrm{gx}}$ and $C_{\text {gy }}$ are the group velocity components on zonal and meridional directions; $\bar{U}$ and $\bar{V}$ are the mean zonal and meridional winds; $q$ is the mean absolute vorticity; $K, k$, and $l$ are the total wave number, zonal wavenumber, and meridional wavenumber, respectively. The ray path is integrated using a fourth-order Runge-Kutta method.

$C_{\mathrm{gx}}=\bar{U}+\frac{\left(k^{2}-l^{2}\right) q_{y}-2 k l q_{x}}{K^{4}}$

$C_{\mathrm{gy}}=\bar{V}+\frac{\left(k^{2}-l^{2}\right) q_{x}+2 k l q_{y}}{K^{4}}$

Under the average conditions in May-August derived from ERA-Interim at $200 \mathrm{hPa}$ with NINO4 $>0.5$ or NINO4 $<-0.5$, we released rays with a total wavenumber matching with the mean flow at the extratropical location of the OLR anomaly $\left(140-150^{\circ} \mathrm{E}, 25-30^{\circ} \mathrm{N}\right)$. For quasi-stationary waves, the wavenumber is determined by the basic zonal flow and background absolute vorticity gradient through the Rossby wave dispersion relation. For the NINO4 > 0.5 May-August condition, $\mathrm{K}=4.14$. With this total wavenumber and launching angle from 0 to $60^{\circ}$ relative to the zonal direction, Rossby wave rays (coloured by red, orange to blue according to their angle from 0 to $60^{\circ}$ ) released at $140^{\circ} \mathrm{W}, 20^{\circ} \mathrm{N}$ can propagate successfully to western Canada for those with smaller launching angles $\left(<30^{\circ}\right)$ as shown in the bottom plot in Fig. 9. With NINO4 $<-0.5$, the zonal wind in the source region is weaker, and the meridional gradient of absolute vorticity is stronger due to its southern position relative to the subtropical jet. The total wavenumber for stationary Rossby waves is 6.2 , determined by the mean May-August condition for NINO4<-0.5. The waves with shorter wavelength tend to be evanescent near the source region as shown in the top plot in Fig. 9. However, there is no significant difference in ray path under the NINO4 $<-0.5$ condition compared to NINO4 $>0.5$ if the source wavenumbers are set to the same value (results not shown). The changes in the mean conditions in the midlatitudes away from the source region from El Niño to La Niña are not sufficient to alter the propagation condition for quasi-stationary Rossby waves.

\section{Discussion}

The summer of 2015 is the first summer after the development of El Niño during the 2014-2015 winter. Though the upper-level GPH pattern, seen in summer 2015, can be attributed to the SST modes in the Pacific, namely ENSO and NPM, the precipitation in the western Canadian Prairies is not strongly correlated with either. Bonsal and Lawford (1999) found that more extended dry spells tend to occur in the Canadian Prairies during the second summer following the mature stage of the El Niño events. The winter precipitation in Canada has a strong connection to ENSO (Shabbar et al., 1997), whereas summer precipitation, in most regions of western Canada (except the coast of British Columbia and Southern Alberta), does not have a significant correlation with ENSO. This is consistent with our investigation using instrumental records from 1948 to 2016.

Growing season precipitation in the Canadian Prairies is affected by many factors. Precipitation deficits can occur under various circulation and lower boundary conditions. Thus, it is not expected that a universal condition for all the significant droughts in the region can be identified. In fact, extreme drought events have been found in both El Niño and La Niña years. A previous study by Bonsal and Lawford (1999) indicates the meteorological drought often occurs after the mature phase of El Niño, which is not the case for 2015. The associated anomaly in the North Pacific represented by the NPM positive phase is consistent with their results. The direct linkage between ENSO and the summer precipitation in the Canadian Prairies is not clear. In fact, the correlation between MEI and the precipitation in the investigated region is $-0.096(p=0.239$, sample size $=152)$. The investigated region's growing season precipitation does not possess a significant correlation with ENSO, which is consistent with other researchers' findings (Dai and Wigley, 2000).

The regression pattern is consistent with stationary Rossby wave theory as shown in a hierarchy of theoretical and modelling studies (Karoly et al., 1989; Simmons et al., 1983; Hoskins and Ambrizzi, 1993; Ambrizzi and Hoskins, 1997; Held et al., 2002). A similar wave train extends from the western Pacific toward extratropical South America but at lower latitudes compared to its counterpart in the Northern Hemisphere (not shown). The node of the wave train in western Canada and the Pacific Northwest of the US corresponds to an anomalous ridge, which is in phase of El Niño forcing. When the convection in the region associated with MJO-4 is weaker than normal (MJO-4>0), a wave train with the opposite sign will reach western Canada, which then counteracts the El Niño forcing. Thus, the weak correlation between Canadian Prairies precipitation and ENSO is understandable as MJO plays an additional role that enhances or cancels out the GPH anomaly caused by El Niño. 

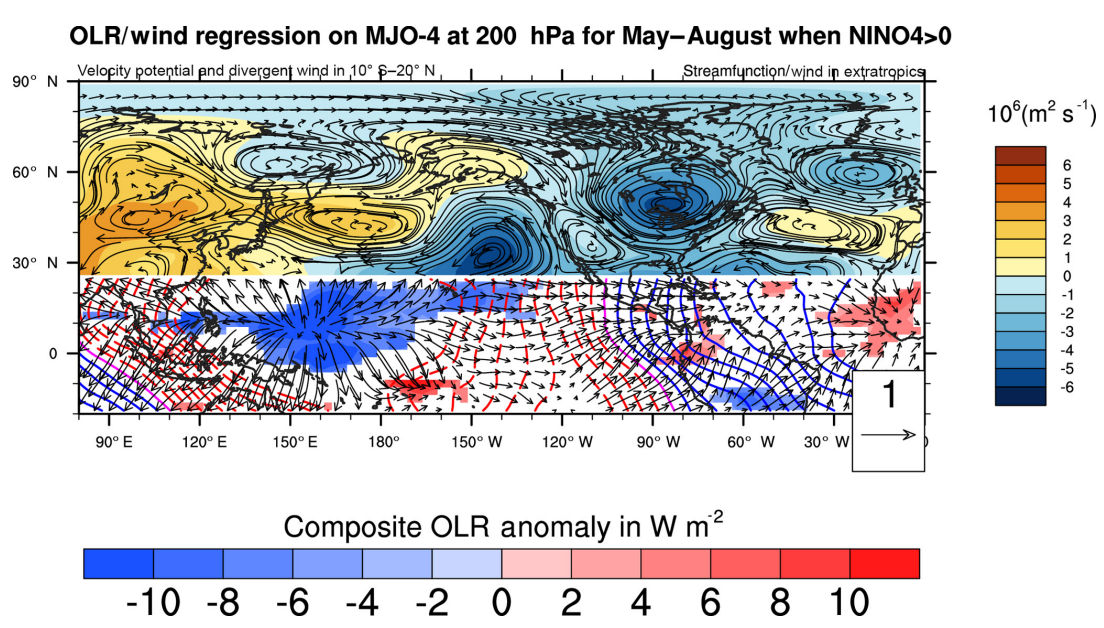

Figure 8. The regression of stream function and wind field in the extratropics on negative MJO-4 for May-August with NINO4 $>0.5$ condition. In the tropics, the regression of OLR, velocity potential, and divergent wind on negative MJO-4 indices for May-August with NINO4 $>0.5$ condition. The shaded region for the tropical OLR has $p$ value $<0.05$. Blue shading indicates active convection region. Red dashed contour and solid blue contour corresponds to negative and positive velocity potential, respectively.
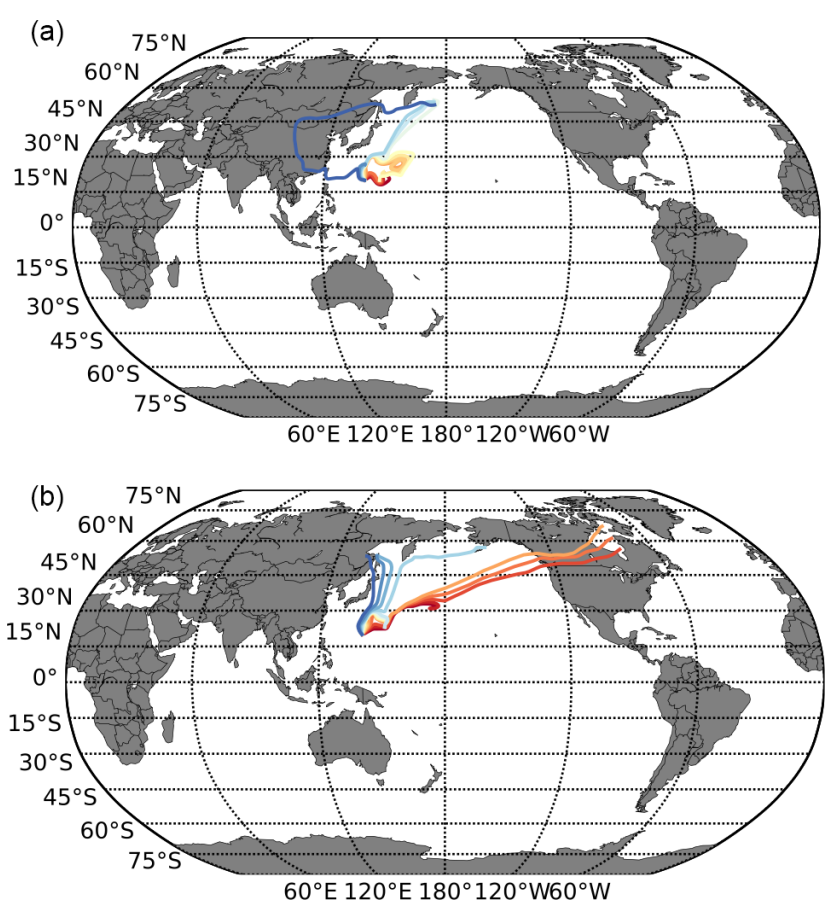

Figure 9. Ray-tracing result with total wavenumber specified by the mean flow $140-150^{\circ} \mathrm{W}$ and $20-30^{\circ} \mathrm{N}$ for mean May-August condition with NINO4 $<-0.5$ (a) and NINO4 $>0.5$ (b). Rays originate from $140^{\circ} \mathrm{E}, 20^{\circ} \mathrm{N}$, with angles ranging from 0 (red) to $60^{\circ}$ (dark blue) from zonal direction.

In the mid-latitude North America, the atmospheric response to the tropical forcing in the western Pacific depends on the mean circulation condition associated with tropical SST. Intraseasonal tropical convection oscillation in the western Pacific associated with the MJO-4 index cannot de- termine the sign of the precipitation anomaly in the Prairies alone. Both warm SST in the central Pacific and strong tropical convection in the western Pacific and Maritime Continent are essential to cause a significant precipitation deficit in the western Canadian Prairies. Warm SST in the central Pacific causes an eastward expansion of Pacific warm pool that favours enhanced MJO activity in the western-central Pacific (Hendon et al., 1999; Marshall et al., 2016). As shown by the ray-tracing result, the NINO4 also affects the wavenumber of the quasi-stationary Rossby waves over the source region in the western Pacific. Under warm NINO4, the wavenumbers tend to be smaller due to stronger westerly winds in the source region and these waves can propagate northeastward into western Canada. Conversely, from May to August under cold NINO4, the westerly flow is weaker, and the meridional vorticity gradient is stronger in the subtropics near the source region. These mean flow conditions correspond to waves with lager wavenumbers that cannot propagate across the dateline.

In the year 2015, the SST anomaly in the Pacific (e.g., ENSO, NPM) coincided with the anomalous ridge on the west coast of Canada. This positive GPH anomaly was associated with the strong negative $\mathrm{MJO} 4$ indices, it then caused a blocking pattern, and suppressed precipitation in the Canadian Prairies in the early summer through the mechanism discussed above. Although the El Niño continued to strengthen in July and August 2015, the active convection associated with MJO in the western Pacific propagated eastward into the central Pacific. As the convection in the western Pacific/Maritime Continent waned, the precipitation in the Canadian Prairies returned to slightly above normal in July. 


\section{Conclusions}

The cause of the 2015 summer precipitation deficit in the western Canadian Prairies is investigated in relation to atmospheric circulation anomalies, SST, and the intraseasonal tropical convection oscillation, MJO. The drought in western Canada is immediately related to an anomalous upper-level ridge that persisted over the west coast of Canada and Alaska since fall 2014. This ridge was likely associated with a developing El Niño that was enhanced by the MJO.

In general, MJO-4 indices demonstrated significant correlation with the meteorological drought over the Canadian Prairies from May to August when the SST in the central Pacific is warm (NINO4>0), which also corresponds to a stronger MJO amplitude in boreal summer. Our study discovered that MJO phase/strength is connected to the anomalous ridge over western Canada through the propagation of stationary Rossby waves from the western Pacific when NINO4 is positive. Though seasonally MJO is weaker in summer, the spring and early summer MJO amplitudes are larger than normal when the central Pacific SST is warmer than normal $(\mathrm{NINO} 4>0)$. The teleconnection between the Canadian Prairies precipitation deficit and MJO is stronger when NINO4 is positive. The underlying cause of this significant correlation between MJO-4 indices and the prairie precipitation in May-August is a stationary Rossby wave train originating from the Maritime Continent and western Pacific which propagates into Canada. The ray-tracing experiments show the main difference between a warm phase of NINO4 and a cold phase is the changes in stationary Rossby wave wavenumber over the source region. Under NINO4>0.5 May-August conditions, the total wavenumber is about 4 and can propagate into western Canada if the waves in the experiments are oriented relatively zonally. Compared to NINO4 $>0.5, \mathrm{NINO} 4<-0.5$ corresponds to a weaker zonal wind and stronger meridional gradient of absolute vorticity in the subtropics of the source region $\left(140-150^{\circ} \mathrm{E}\right)$. Hence, the wavenumbers of stationary Rossby waves from the source region under NINO4 $<-0.5$ are larger (about 6), and these waves fail to reach the western hemisphere. The intra-seasonal predictability of the growing season precipitation in the Canadian Prairies can be potentially improved by including the MJO amplitude and phase factors for medium-range and intra-seasonal projection in addition to the ENSO effect especially when the central-Pacific SST is warm.

Data availability. All the data used in this study are publicly available. For the atmospheric circulation field, both the ERA-Interim dataset (ECMWF, 2017) and the NCEP Reanalysis (NOAA NCEP, 2017) are publicly available through their corresponding institutions. The SST dataset ERSST v4 (NOAA, 2017a) and the SST related NINO4 index (NOAA, 2017b) are publicly available through the NOAA website. The precipitation dataset CMAP (NOAA CPC, 2017a) can be accessed publicly through the NOAA website. The MJO index from the NOAA CPC of the USA (NOAA CPC, 2017b) is available through the NOAA CPC's MJO website. The MJO index (Bureau of Meteorology of Australia, 2017) and archives on MJO are hosted by the Bureau of Meteorology of Australia. MEI (NOAA, 2017c) is publicly available online through the NOAA website. The Interpolated Outgoing Longwave Radiation (OLR) dataset (NOAA, 2017d) is also available online.

Author contributions. ZL and YL conceived of the presented idea. ZL developed the theory and performed the computations and analyses. BB and AM verified the analytical methods. YL supervised the findings of this work. LS improved the texts and figures. All the authors discussed the results and contributed to the final manuscript.

Competing interests. The authors declare that they have no conflict of interest.

Special issue statement. This article is part of the special issue "Understanding and predicting Earth system and hydrological change in cold regions". It is not associated with a conference.

Acknowledgements. We gratefully acknowledge the Natural Sciences and Engineering Research Council of Canada (NSERC) for funding the Changing Cold Regions Network (CCRN) through their Climate Change and Atmospheric Research (CCAR) initiative. Zhenhua Li is supported by the Probing the Atmosphere of the High Arctic project sponsored by the NSERC. Yanping Li gratefully acknowledges the support from the Global Institute of Water Security at the University of Saskatchewan. This research is also supported by Environment and Climate Change Canada (ECCC). We gratefully acknowledge the support from the Changing Cold Region Network (CCRN), Global Water Future (GWF) and Global Institute of Water Security (GIWS) at the University of Saskatchewan.

Edited by: John Hanesiak

Reviewed by: two anonymous referees

\section{References}

Ambrizzi, T. and Hoskins, B. J.: Stationary Rossby-Wave Propagation in a Baroclinic Atmosphere, Q. J. Roy. Meteor. Soc., 123, 919-28, 1997.

Andrews, E. D., Antweiler, R. C., Neiman, P. J., and Ralph, F. M.: Influence of ENSO on Flood Frequency along the California Coast, J. Climate, 17, 337-348, https://doi.org/10.1175/15200442(2004)017<0337:IOEOFF>2.0.CO;2, 2004.

Bonsal, B. R., Chakravarti, A. K., and Lawford, R. G.: Teleconnections between North Pacific SST Anomalies and Growing Season Extended Dry Spells on the Canadian Prairies, Int. J. Climatol., 13, 865-878, 1993. 
Bonsal, B. R., Zhang, X., and Hogg, W. D.: Canadian Prairie growing season precipitation variability and associated atmospheric circulation, Climate Res., 11, 191-208, 1999.

Bonsal, B. and Lawford, R.: Teleconnections between El Niño and La Niña Events and Summer Extended Dry Spells on the Canadian Prairies, Int. J. Climatol., 19, 1445-1458, 1999.

Bonsal, B. R. and Wheaton, E.: Atmospheric circulation comparisons between the 2001 and 2002 and the 1961 and 1988 Canadian Prairie droughts, Atmos. Ocean, 43, 163-172, 2005.

Bonsal, B. R. and Regier, M.: Historical Comparison of the 2001/2002 Drought in the Canadian Prairies, Clim. Res., 33, 229-242, 2007.

Bonsal, B. R., Aider, R., Gachon, P., and Lapp, S.: An Assessment of Canadian Prairie Drought: Past, Present, and Future, Clim. Dynam., 41, 501-516, 2013.

Bureau of Meteorology of Australia: MJO index, available at: http: //www.bom.gov.au/climate/mjo/, last access: 10 April 2017.

Carbone, R. E. and Li, Y.: Tropical Oceanic Rainfall and Sea Surface Temperature Structure: Parsing Causation from Correlation in the MJO, J. Atmos. Sci., 72, 2703-2718. 2015.

Cassou, C.: Intraseasonal Interaction Between the Madden-Julian Oscillation and the North Atlantic Oscillation, Nature, 455, 523527, 2008.

Dai, A. and Wigley, T. M. L.: Global Patterns of ENSO-Induced Precipitation, Geophys. Res. Lett., 27, 1283-1286, 2000.

Dee, D. P., Uppala, S. M., Simmons, A. J., Berrisford, P., Poli, P., Kobayashi, S., Andrae, U., Balmaseda, M. A., Balsamo, G., Bauer, P., Bechtold, P., Beljaars, A. C. M., van de Berg, L., Bidlot, J., Bormann, N., Delsol, C., Dragani, R., Fuentes, M., Geer, A. J., Haimberger, L., Healy, S. B., Hersbach, H., Hólm, E. V., Isaksen, L., Kållberg, P., Köhler, M., Matricardi, M., McNally, A. P., Monge-Sanz, B. M., Morcrette, J.-J., Park, B.-K., Peubey, C., de Rosnay, P., Tavolato, C., Thépaut, J.-N., and Vitart, F.: The ERA-Interim Reanalysis: Configuration and Performance of the Data Assimilation System, Q. J. Roy. Meteor. Soc., 137, 553597, 2011

Dey, B.: Nature and Possible Causes of Droughts on the Canadian Prairies-Case Studies, J. Climatol., 2, 233-249, 1982.

ECMWF: ERA-interim Dataset, available at: https://www.ecmwf. int/en/forecasts/datasets/archive-datasets/reanalysis-datasets/ era-interim, last access: 15 August 2017.

Garfinkel, C. I., Feldstein, S. B., Waugh, D. W., Yoo, C., and Lee, S.: Observed Connection Between Stratospheric Sudden Warmings and the Madden-Julian Oscillation, Geophys. Res. Lett., 39, L18807, https://doi.org/10.1029/2012GL053144, 2012.

Hanesiak, J. M., Stewart, R. E., Bonsal, B. R., Harder, P., Lawford, R., Aider, R., Amiro, B. D., Atallah, E., Barr, A. G., Black, T. A., Bullock, P., Brimelow, J. C., Brown, R., Carmichael, H., Derksen, C., Flanagan, L. B., Gachon, P., Greene, H., Gyakum, J., Henson, W., Hogg, E. H., Kochtubajda, B., Leighton, H., Lin, C., Luo, Y., McCaughey, J. H., Meinert, A., Shabbar, A., Snelgrove, K., Szeto, K., Trishchenko, A., van der Kamp, G., Wang, S., Wen, L., Wheaton, E., Wielki, C., Yang, Y., Yirdaw, S., and Zha, T.: Characterization and summary of the 19992005 canadian prairie drought, Atmos. Ocean, 49, 421-452, https://doi.org/10.1080/07055900.2011.626757, 2011.

Hartmann, D. L.: Pacific Sea Surface Temperature and the Winter of 2014, Geophys. Res. Lett., 42, 1894-902, 2015.
Held, I. M., Ting, M., and Wang, H.: Northern Winter Stationary Waves: Theory and Modeling, J. Climate, 15, 2125-2144, 2002.

Hendon, H. H., Zhang, C., and Glick, J. D.: Interannual variation of the Madden-Julian Oscillation during Austral summer, J. Climate, 12, 2538-2550, 1999.

Hendon, H. H., Wheeler, M. C., and Zhang, C.: Seasonal dependence of the MJO-ENSO relationship, J. Climate, 20, 531-543, https://doi.org/10.1175/JCLI4003.1, 2007

Hoskins, B. J. and Ambrizzi, T.: Rossby Wave Propagation on a Realistic Longitudinally Varying Flow, J. Atmos. Sci., 50, 16611671, 1993.

Hoskins, B. J. and Karoly, D. J.: The Steady Linear Response of a Spherical Atmosphere to Thermal and Orographic Forcing, J. Atmos. Sci., 38, 1179-1196, 1981.

Hoskins, B. J. and Ambrizzi, T.: Rossby Wave Propagation on a Realistic Longitudinally Varying Flow, J. Atmos. Sci., 50, 16611671, 1993.

Huang, B., Banzon, V. F., Freeman, E., Lawrimore, J., Liu, W., Peterson, T. C., Smith, T. M., Thorne, P. W., Woodruff, S. D., and Zhang, H.-M.: Extended Reconstructed Sea Surface Temperature Version 4 (ERSST. v4). Part I: Upgrades and Intercomparisons, J. Climate, 28, 911-930, 2015.

Kalnay, E., Kanamitsu, M., Kistler, R., Collins, W., Deaven, D., Gandin, L., Iredell, M., Saha, S., White, G., Woollen, J., Zhu, Y., Chelliah, M., Ebisuzaki, W., Higgins, W., Janowiak, J., Mo, K., Ropelewski, C., Wang, J., Leetmaa, A., Reynolds, R., Jenne, R., and Joseph, D.: The NCEP/NCAR 40-Year Reanalysis Project, B. Am. Meteorol. Soc., 77, 437-471, 1996.

Karoly, D. J., Plumb, R. A., and Ting, M.: Examples of the Horizontal Propagation of Quasi-Stationary Waves, J. Atmos. Sci., 46, 2802-2811, 1989.

Lee, M. Y., Hong, C. C., and Hsu, H. H.: Compounding Effects of Warm Sea Surface Temperature and Reduced Sea Ice on the Extreme Circulation Over the Extratropical North Pacific and North America During the 2013-2014 Boreal winter, Geophys. Res. Lett., 42, 1612-1618, 2015.

Li, Y. and Carbone, R. E.: Excitation of rainfall over the tropical western Pacific, J. Atmos. Sci., 69, 2983-2994, 2012.

Li, Y., Szeto, K., Stewart, R., Theriault, J., Chen, L., Kochtubajda, B., Liu, A., Boodoo, S., Goodson, R., Mooney, C., and Kurkute, S.: The June 2013 Alberta Catastrophic Flooding: Water vapor transport analysis by WRF simulation, J. Hydrometeorol., 18, 2057-2078, 2017.

Li, Z., Manson, A., Li, Y., and Meek, C.: Circulation Characteristics of Persistent Cold Spells in Central-Eastern North America, J. Meteorol. Res., 31, 250-260, 2017.

Liu, J., Stewart, R. E., and Szeto, K. K.: Moisture Transport and Other Hydrometeorological Features Associated With the Severe 2000/01 Drought Over the Western and Central Canadian Prairies, J. Climate, 17, 305-319, 2004.

Liu, A., Mooney, C., Szeto, K., Thériault, J. M., Kochtubajda, B., Stewart, R. E., Boodoo, S., Goodson, R., Li, Y., and Pomeroy, J.: The June 2013 Alberta Catastrophic Flooding Event: Part 1 Large scale features, Hydrol. Process., 2016, 4899-4916, 2016.

Lorenz, D. J. and Hartmann, D. L.: The Effect of the MJO on the North American Monsoon, J. Climate, 19, 333343, https://doi.org/10.1175/JCLI3684.1, 2006. 
Madden, R. A. and Julian, P. R.: Detection of a 40-50 Day Oscillation in the Zonal Wind in the Tropical Pacific, J. Atmos. Sci., 28, 702-708, 1971.

Marshall, A. G., Hendon, H. H., and Wang, G.: On the role of anomalous ocean surface temperatures for promoting the record Madden-Julian Oscillation in March 2015, Geophys. Res. Lett., 43, 472-481, 2016.

NOAA CPC: CMAP, available at: http://www.cpc.ncep.noaa. gov/products/global_precip/html/wpage.cmap.html, last access: 15 August 2017a.

NOAA CPC: MJO CPC index, available at: http://www.cpc.ncep. noaa.gov/products/precip/CWlink/MJO/mjo.shtml, last access: 15 August 2017b.

NOAA NCEP: NCEP Reanalysis, available at: https://www. esrl.noaa.gov/psd/data/gridded/data.ncep.reanalysis.html, last access: 15 August 2017.

NOAA: ERSST-V4, available at: https://www. ncdc.noaa.gov/data-access/marineocean-data/ extended-reconstructed-sea-surface-temperature-ersst-v4, last access: 15 August 2017a.

NOAA: NINO4 index, available at: https://www.esrl.noaa.gov/psd/ gcos_wgsp/Timeseries/Nino4/, last access: 15 August 2017b.

NOAA: MEI, available at: https://www.esrl.noaa.gov/psd/enso/ mei/, last access: 15 August 2017c.

NOAA: Interpolated OLR, available at: https://www.esrl.noaa. gov/psd/data/gridded/data.interp_OLR.html, last access: $15 \mathrm{Au}-$ gust 2017d.

Rayner, N. A., Parker, D. E., Horton, E. B., Folland, C. K., Alexander, L. V., Rowell, D. P., Kent, E. C., and Kaplan, A.: Global analyses of sea surface temperature, sea ice, and night marine air temperature since the late nineteenth century. J. Geophys. Res., 108, 4407, https://doi.org/10.1029/2002JD002670, 2003.

Riddle, E. E., Stoner, M. B., Johnson, N. C., L'Heureux, M. L., Collins, D. C., and Feldstein, S. B.: The Impact of the MJO on Clusters of Wintertime Circulation Anomalies Over the North American region, Clim. Dynam., 40, 1749-1766, 2013.

Rodney, M., Lin, H., and Derome, J.: Subseasonal Prediction of Wintertime North American Surface Air Temperature during Strong MJO Events, Mon. Weather Rev., 141, 2897-2909, https://doi.org/10.1175/MWR-D-12-00221.1, 2013.

Shabbar, A., Bonsal, B., and Khandekar, M.: Canadian precipitation patterns associated with the Southern Oscillation, J. Climate, 10, 3016-3027, 1997.

Shabbar, A. and Skinner, W.: Summer Drought Patterns in Canada and the Relationship to Global Sea Surface Temperatures, J. Climate, 17, 2866-2880, 2004.

Shabbar, A., Bonsal, B. R., and Szeto, K.: Atmospheric and Oceanic Variability Associated with Growing Season Droughts and Pluvials on the Canadian Prairies, Atmos. Ocean, 49, 339-355, 2011.
Simmons, A. J. and Hoskins, B. J.: Barotropic influences on the growth and decay of nonlinear baroclinic waves, J. Atmos. Sci., 37, 1679-1684, https://doi.org/10.1175/15200469(1980)037<1679:BIOTGA>2.0.CO;2, 1980.

Simmons, A. J., Wallace, J. M., and Branstator, G. W.: Barotropic Wave Propagation and Instability, and Atmospheric Teleconnection Patterns, J. Atmos. Sci., 40, 1363-1392, 1983.

Szeto, K., Zhang, X., White, R. E., and Brimelow, J.: The 2015 Extreme Drought in Western Canada, B. Am. Meteorol. Soc., 97, S42-S46, https://doi.org/10.1175/BAMS-D-16-0147.1, 2016.

Wang, S. Y., Hipps, L., Gillies, R. R., and Yoon, J.-H.: Probable Causes of the Abnormal Ridge Accompanying the 2013-2014, California Drought: ENSO Precursor and Anthropogenic Warming footprint, Geophys. Res. Lett., 41, 3220-3226, 2014.

Wheaton, E., Wittrock, V., Kulshreshtha, S., Koshida, G., Grant, C., Chipanshi, A., and Bonsal, B. R.: Lessons Learned from the Drought Years of 2001 and 2002: Synthesis Report, Agriculture and Agri-Food Canada, Saskatchewan Research Council Publ. No. 11602-46E03, Saskatoon, 2005.

Wheeler, M. C. and Hendon, H. H.: An all-season real-time multivariate MJO index: Development of an index for monitoring and prediction, Mon. Weather Rev., 132, 1917-1932, 2004.

Wolter, K.: The Southern Oscillation in surface circulation and climate over the tropical Atlantic, Eastern Pacific, and Indian Oceans as captured by cluster analysis, J. Clim. Appl. Meteorol., 26, 540-558, 1987.

Wolter, K. and Timlin, M. S.: Monitoring ENSO in COADS with a seasonally adjusted principal component index. Proc. of the 17th Climate Diagnostics Workshop, Norman, OK, NOAA/NMC/CAC, NSSL, Oklahoma Clim. Survey, CIMMS and the School of Meteor., Univ. of Oklahoma, 52-57, 1993.

Xie, P. and Arkin, P. A.: Global Precipitation: A 17-year Monthly Analysis Based on Gauge Observations, Satellite Estimates, and Numerical Model Outputs, B. Am. Meteorol. Soc., 78, 25392558, 1997.

Xue, Y., Higgins, W., and Kousky, V.: Influences of the MaddenJulian Oscillations on Temperature and Precipitation in North America during ENSO-neutral and Weak ENSO Winters, Proc. workshop on prospects for improved forecasts of weather and short-term climate variability on subseasonal ( 2 week to 2 month) time scales, 2002.

Zhang, C.: Madden-Julian Oscillation, Rev. Geophys., 43, RG2003, https://doi.org/10.1029/2004RG000158, 2005. 